\title{
Menetus dilatatus (Gould, 1841) (Gastropoda: Planorbidae) in the Lipno Reservoir (Southern Bohemia, Czech Republic)
}

\author{
LUBOŠ BERAN \\ KokořínskoProtected Landscape Area Administration, Česká 149, CZ-27601 Mělník, Czech Republic, e-mail: \\ lubos.beran@schkocr.cz
}

\begin{abstract}
BERAN L., 2005: Menetus dilatatus (Gould, 1841) (Gastropoda: Planorbidae) in the Lipno Reservoir (Southern Bohemia, Czech Republic). - Malacologica Bohemoslovaca, 4: 17-20. Online serial at $<$ http://mollusca.sav.sk $>$ 5-Oct-2005.

Menetus dilatatus (Gould, 1841) has been found in July 2005 in the Lipno Reservoir (Bohemian Forest = Šumava Mts., Southern Bohemia, Czech Republic) at 12 particular sites. This locality is about $80 \mathrm{~km}$ south of the nearest known locality of Menetus dilatatus and more than $160 \mathrm{~km}$ south of the Elbe Lowland where Menetus dilatatus occurs in many sites including the Elbe River. The altitude of the Lipno Reservoir reaches $725 \mathrm{~m}$ a.s.l. and is the highest known altitude of Menetus dilatatus in the Czech Republic.
\end{abstract}

\section{Introduction}

Menetus dilatatus (Gould, 1841) is a native mollusc in the Nearctic Region in the eastern part of the U.S.A. (KERNEY 1999). Up to now only one species of the genus Menetus H. \& A. Adams, 1855 which was introduced from North America to Europe. In Europe it has been recorded for the first time in Great Britain in 1869 (KERNEY 1999). Today it is known mainly from Western and Central Europe. Recent distribution in Europe is presented in MÜLLER et al. (2005). In the Czech Republic this species has been recorded for the first time in 1994 from a sandpit near Kolín (BERAN 1994). The distribution up to 1996 is presented in BERAN (1997) and data up to 2001 are summarised in BERAN (2002). The localities of this species are concentrated in the Elbe Lowland between Ústí nad Labem and Týnec nad Labem from altitude 151-235 m a.s.1. (BERAN 2002). In 2002, Menetus dilatatus has been found in the Otava River in the Orlík Reservoir (Southern Bohemia) in altitude about $350 \mathrm{~m}$ a.s.l. This locality is more than $80 \mathrm{~km}$ south of localities in the Elbe Lowland (BERAN 2003).

\section{Material and Methods}

In 2005, the author studied aquatic molluscs of the Lipno Reservoir (Bohemian Forest, Southern Bohemia, Czech Republic). The Lipno Reservoir was built in 1960 on the Vltava River near the town of Vyšś Brod in altitude $725 \mathrm{~m}$ a.s.l. With an area of 4870 ha (capacity $306000000 \mathrm{~m}^{3}$ ) it is the largest water body in the Czech Republic (VLČEK et al. 1984).

The main sampling method for aquatic molluscs is washing vegetation or sediments with a metal sieve (a kitchen strainer, diameter $20 \mathrm{~cm}$, mesh size $0.5-1 \mathrm{~mm}$ ) in combination with searching of stones, wood and waste (plastic bags and bottles). This method was also used in this case when shallow and overgrown places or stones near banks of the water reservoir were searched. Molluscs were determined by their conchs.

Conchs of Menetus dilatatus from selected sites are deposited in author's collection.

\section{Results and Discussion}

Menetus dilatatus has been found in July 2005 in the Lipno Reservoir at particular sites mentioned below. 
Data presented are as follows: geographical coordinates, code of the mapping field for faunistic grid mapping (cf. PRUNER \& MíKA 1996), name of the nearest settlement, description of the site, number of individuals, and date of investigation.

1 - 48 $37^{\prime} 59^{\prime \prime} \mathrm{N}, 14^{\circ} 13^{\prime} 52^{\prime \prime}$ E, 7351, Lipno nad Vltavou, Lipno Reservoir in the south-eastern part of the water reservoir ca $300 \mathrm{~m}$ from the dam, 3 specimens, 25 July 2005;

2 - 48 $38^{\prime} 25^{\prime \prime} \mathrm{N}, 1^{\circ} 12^{\prime} 43^{\prime \prime}$ E, 7351, Lipno nad Vltavou, Lipno Reservoir at a village, 4 spec. (coll.), 29 July 2005 ;

3 - 48³7'50" N, 14¹0'28" E, 7351, Přední Výtoň, Lipno Reservoir at avillage, 3 spec., 24 July 2005; 4 - 48³9'32" N, 1409'54" E, 7351, Frymburk, Lipno Reservoir at a village near a ferry, 3 spec., 27 July 2005;

5 - 48 $41^{\circ} 26^{\prime \prime}$ N, 1407'02" E, 7350, Kovářov, Lipno Reservoir west and north-west of a village, 10 spec., 29 July 2005; $6-48^{\circ} 40^{\prime} 29^{\prime \prime} \mathrm{N}, 14^{\circ} 03^{\prime} 47^{\prime \prime} \mathrm{E}, 7350$, Kyselov, bank of the Lipno Reservoir in the Rakovská Zátoka bay near a road, 3 spec., 24 July 2005 ;

$7-48^{\circ} 41^{\prime} 15^{\prime \prime} \mathrm{N}, 14^{\circ} 04^{\prime} 03^{\prime \prime} \mathrm{E}, 7350$, Kyselov, bank of the Lipno Reservoir near a ferry, 20 spec., 24 July 2005;

8 - 48 $43^{\prime} 00^{\prime \prime} \mathrm{N}, 1^{\circ} 04^{\prime} 16^{\prime \prime} \mathrm{E}, 7250$, Radslav, Lipno Reservoir at a village, 30 spec. (coll.), 29 July 2005; 9 - 4844'06" N, 1403'13" E, 7250, Přední Zvonková, Lipno Reservoir near Valtrov, 6 spec., 26 July 2005; 10 - 48 44'18" N, 1406'03" E, 7250, Černá v Pošumaví, Lipno Reservoir near a marina (left side of the road Černá v Pošumaví - Hůrka), 20 spec. (coll.), 25 July 2005;

11 - 4844'22" N, 1406'16" E, 7250, Černá v Pošumaví, the bay of the Lipno Reservoir on the right side of the road Černá v Pošumaví - Hůrka, 15 spec., 25 July 2005 ;

12 - 4845'36" N, 1401'18" E, 7250, Horní Planá, Lipno Reservoir near a ferry, 2 spec., 26 July 2005.

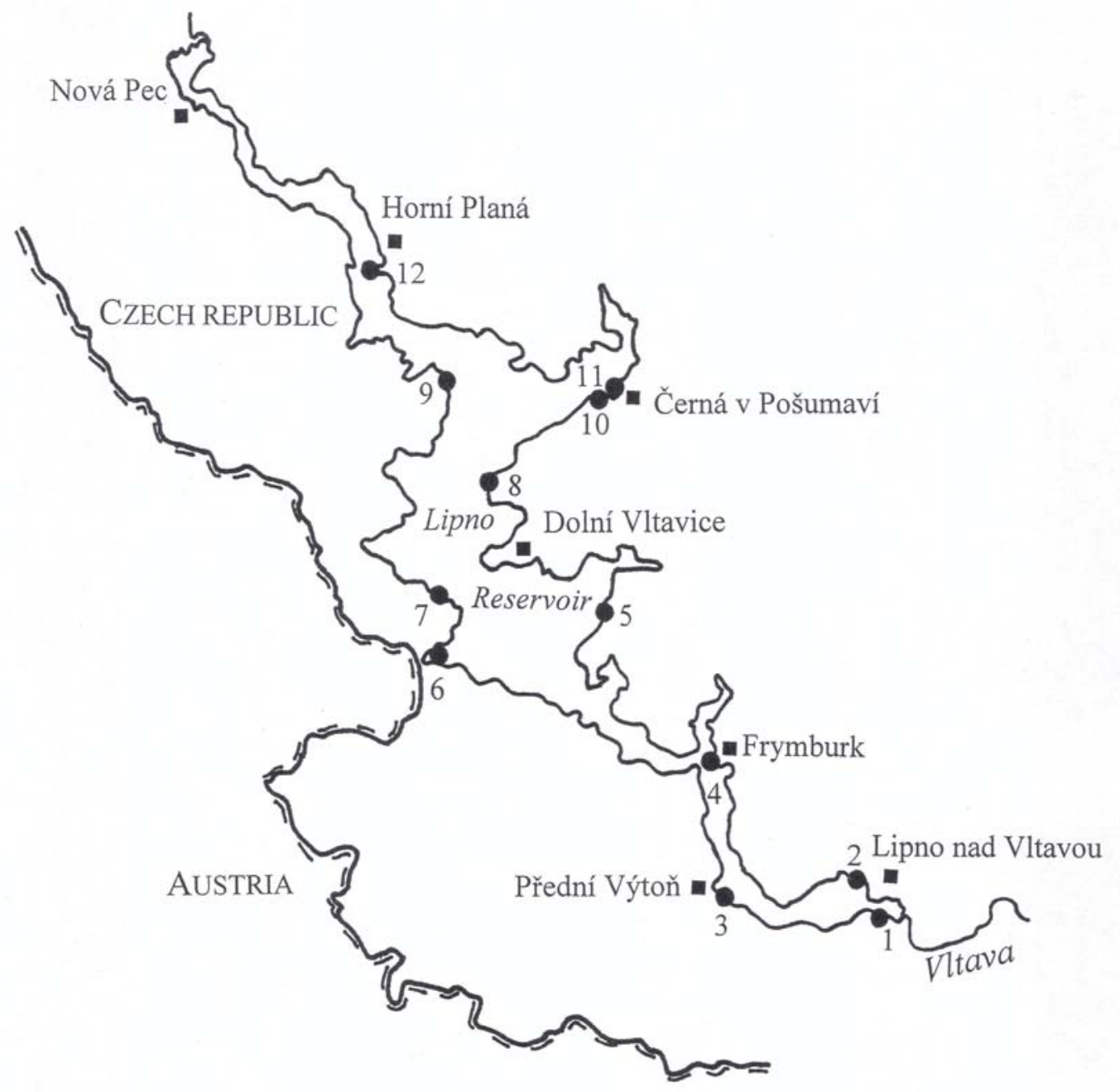

Fig. 1. The map of the Lipno Reservoir with localities under study. 
Thus, it is evident that Menetus dilatatus occurs at a large part of this water reservoir. Menetus dilatatus has been found at particular localities mainly on the stones on the banks of the water reservoir together mainly with Radix auricularia (Linnaeus, 1758), R. ovata (Draparnaud, 1805) $=R$. balthica (Linnaeus, 1758) sensu GLÖER \& MEIER-BROOK (2003), and Gyraulus albus (O.F. Müller, 1774). Bigger stones (one dimension at least $10 \mathrm{~cm}$ ), respectively their sides opposite of the water level were preferable habitats, when the highest density (6 individuals per approx. $150 \mathrm{~cm}^{2}-$ one side of the stone, loc. 8) was documented. Its occurrence on the vegetation together with more than 10 other species as Acroloxus lacustris (Linnaeus, 1758), Stagnicola corvus (Gmelin, 1791), R. ovata (Draparnaud, 1805), Lymnaea stagnalis (Linnaeus, 1758), Physa fontinalis (Linnaeus, 1758), Anisus leucostoma (Millet, 1813), Bathyomphalus contortus (Linnaeus, 1758), Gyraulus albus (O.F. Müller, 1774), G. crista (Linnaeus, 1758), Hippeutis complanatus (Linnaeus, 1758), Planorbarius corneus (Linnaeus, 1758) were also observed during washing vegetation with a metal sieve. All individuals of this species were found at depth 5-70 $\mathrm{cm}$ from the water level.

Aquatic molluscs of the Lipno Reservoir were studied by L. Dvořák mainly in November 2003 when the water level was $3.5 \mathrm{~m}$ lower than maximum stage
(DVOŘÁK \& BERAN 2004). Menetus dilatatus was not found but research was directed to unionids and conditions for searching of gastropods living on stones or on the vegetation were not favourable.

The Lipno Reservoir is situated about $80 \mathrm{~km}$ south of the known locality of Menetus dilatatus in the Otava River in the Orlík Reservoir (BERAN 2003) and more than $160 \mathrm{~km}$ south of the Elbe Lowland where Menetus dilatatus occurs in many sites including the Elbe River (BERAN 2002). This is the second case when Menetus dilatatus was found in the large water reservoir. Thus, it will be useful to give consideration to occurrence of Menetus dilatatus in further large water reservoirs mainly in the Vltava River Basin. The altitude of the Lipno Reservoir reaches $725 \mathrm{~m}$ a.s.l. This altitude is the highest known altitude of the occurrence of Menetus dilatatus in the Czech Republic and it is more than $500 \mathrm{~m}$ higher than the altitude of the sites in the Elbe Lowland but it is necessary to note that so large water reservoir makes conditions for existence of population of Menetus dilatatus more suitable. The same phenomenon was documented also in the case of several other species living in the Lipno Reservoir presented in DVOŘÁK \& BERAN (2004) or at the text above when the altitude of the Lipno Reservoir is the highest known altitude of their occurrence in the Czech Republic.

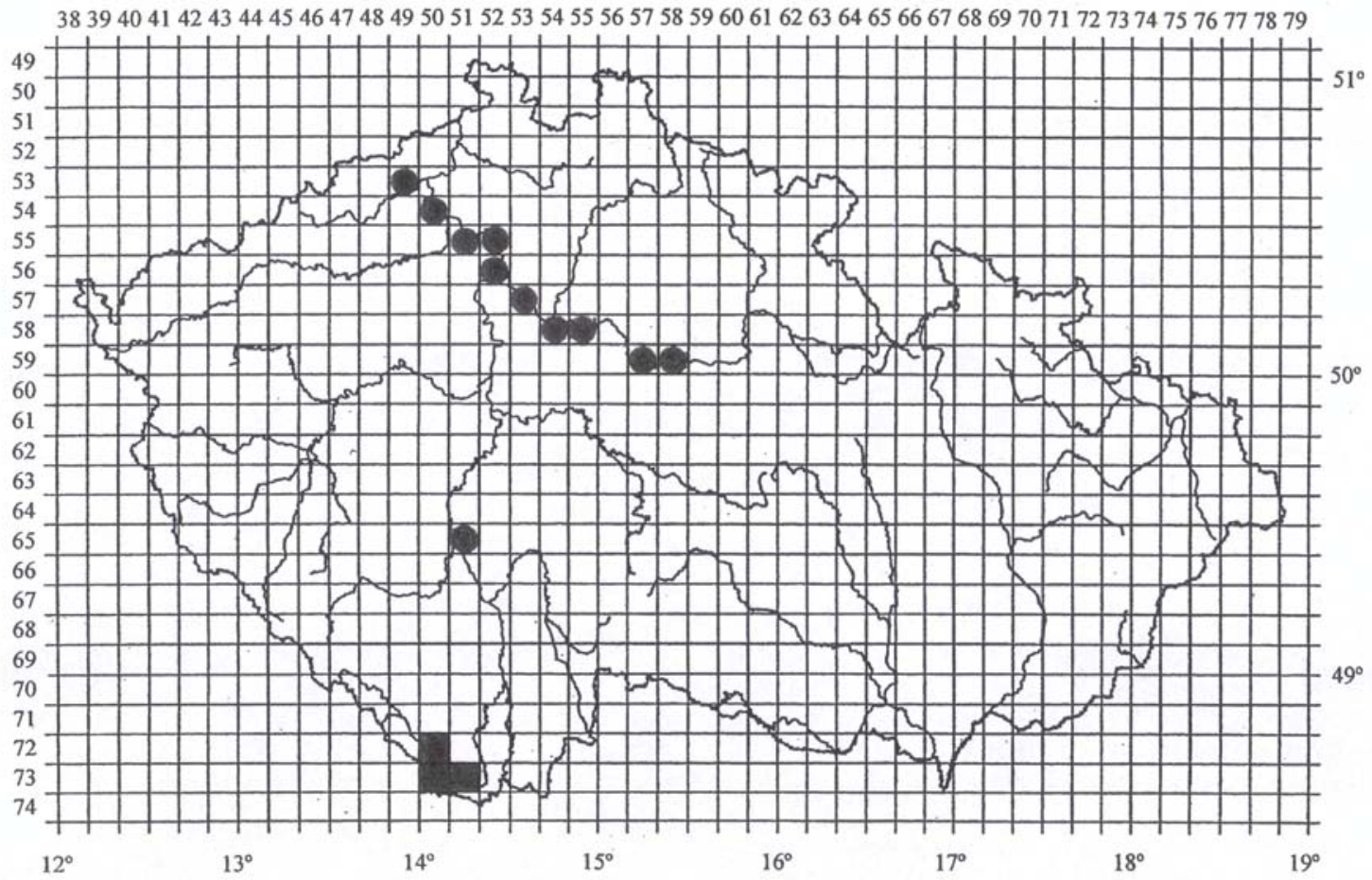

Fig. 2. The map for faunistic grid mapping showing the known distribution of Menetus dilatatus in the Czech Republic. Full circle - adopted from BERAN (2003), full mapping field - new records presented above. 


\section{References}

BERAN L., 1994: Severoamerický okružák Menetus dilatatus (Gould) v České republice [The found of North American species Menetus dilatatus (Gould) in the Czech Republic (Mollusca: Gastropoda)]. - Práce muzea v Kolíně, řada př́rodovědná, 1: 31-32.

BERAN L., 1997: Menetus dilatatus (Gould, 1841) (Mollusca, Gastropoda) in the Czech Republic. Časopis Nár. muz., Řada př́rodovědná, Vol. 166 (1-4): 59-62.

BERAN L., 2002: Vodní měkkýši České republiky rozšíření a jeho změny, stanoviště, širření, ohrožení a ochrana, červený seznam [Aquatic molluscs of the Czech Republic - distribution and its changes, habitats, dispersal, threat and protection, Red List]. - Sborník přírodovědného klubu v Uh. Hradišti, Supplementum 10, 258 pp.

BERAN L., 2003: Nález severoamerického druhu Menetus dilatatus (Mollusca: Gastropoda) v jižních Čechách (Česká republika) [Record of Menetus dilatatus (Mollusca: Gastropoda) in the Southern Bohemia (Czech Republic)]. - Malacologica Bohemoslovaca, 2: 1-2.

DVOŘÁK L. \& BERAN L., 2004: Remarkable records of aquatic molluscs in the Lipno Reservoir and its environs. - Silva Gabreta, 10: 97-106.
GlÖER P. \& MeIER-BrooK C., 2003: Süsswassermollusken (Ein Bestimmungsschlüssel für die Bundesrepublik Deutschland). - 13. Auflage, Deutscher Jugenbund für Naturbeobachtung, Hamburg, $136 \mathrm{pp}$.

KERNEY M., 1999: Atlas of the Land and Freshwater Molluscs of Britain and Ireland. - Harley Books, London, $261 \mathrm{pp}$.

Müller R., Anlauf A. \& Schleuter M., 2005: Nachveise der Neozoe Menetus dilatatus (Gould, 1841) in der Oberelde, Mittelelbe, dem Mittellandkanal und dem Nehmitzsee (Sachsen, Sachsen-Anhalt, Brandenburg) (Gastropoda: Planorbidae). - Malak. Abh., 23: 77-85.

PRUNER L. \& MíKA P., 1996. Seznam obcí a jejich částí v České republice s čísly mapových polí pro sít'ové mapování fauny [List of settlements in the Czech Republic with associated map field codes for faunistic grid mapping system]. - Klapalekiana, 32 (Suppl.): 1-175.

VlČeK V., KestřáneK J., KŘíž H., NOVOtnÝ S. \& PíŠE J., 1984: Vodní toky a nádrže Zeměpisný lexikon ČSR [Water bodies and reservoirs. Geographical lexicon of Czechoslovakia]. - Academia, Praha, 316 pp. 